\title{
TERRITÓRIOS VERTICAIS:
}

\section{GRAFISMOS URBANOS NO HIPERCENTRO DE BELO HORIZONTE (MG)}

\author{
Alexandre Magno Alves Diniz \\ Pontifícia Universidade Católica de Minas Gerais - PUC Minas \\ Professor Adjunto IV - Programa de Pós-graduação em Geografia \\ alexandremadiniz@gmail.com \\ Rodrigo Guedes Braz Ferreira \\ Pontifícia Universidade Católica de Minas Gerais - PUC Minas \\ Mestrando - Programa de Pós-graduação em Geografia \\ rodriguedes13@hotmail.com \\ Angélica Goncalves Lacerda \\ Pontifícia Universidade Católica de Minas Gerais - PUC Minas \\ Bolsista de iniciação científica - Programa de Pós-graduação em Geografia \\ angelicalacerda50@gmail.com
}

\begin{abstract}
RESUMO
O presente estudo versa sobre a apropriação e a ressignificação do Hipercentro de Belo Horizonte por artistas de rua. Uma catalogação dos grafismos urbanos foi realizada em três momentos (2011, 2015 e 2017), buscando-se identificar formas predominantes de estilos, modos de aplicação, além da posição dos grafismos nas edificações e na paisagem urbana. Os dados levantados em campo foram submetidos a análises espaciais e estatísticas. Os resultados deste trabalho confirmam a natureza transiente da paisagem do Hipercentro de Belo Horizonte e o seu forte caráter identitário, onde atores hegemônicos e hegemonizados disputam o domínio sobre muros, fachadas, monumentos, viadutos e equipamentos urbanos, gerando territorialidades horizontais e verticais.
\end{abstract}

Palavras-Chave: Pichação. Território. Conflito Espacial. Belo Horizonte.

\section{VERTICAL TERRITORIES:}

\section{URBAN GRAPHICS IN THE HYPERCENTER OF BELO HORIZONTE (MG)}

\begin{abstract}
The present study deals with the appropriation and re-signification of the Hypercenter of Belo Horizonte by street artists. The cataloging of the urban graphics was carried out in three moments (2011, 2015 and 2017), searching for more predominant forms of styles, modes of application, besides the predominant position of urban graphics in the buildings and in the urban landscape. Data gathered in the field were subjected to spatial and statistical analyses. The results of this work confirm the transient nature of Belo Horizonte's Hypercenter landscape and its character, where hegemonic and hegemonized actors compete for the dominance over walls, facades, monuments, viaducts and urban equipment, generating horizontal and vertical territorialities.
\end{abstract}

Key words: Graffiti. Territory. Spatial Conflict. Belo Horizonte.

\section{INTRODUÇÃO}

O hipercentro de Belo Horizonte é caracterizado por diversas intervenções gráficas em marquises, topo de edificações, muros, fachadas e portas de lojas, muitas das quais 
ininteligíveis, produzidas por sujeitos ou grupos que utilizam a paisagem urbana para se expressar. Essas variadas intervenções gráficas, por sua vez, são objeto de acerbas polêmicas, polarizando opiniões envolvendo artistas de rua, órgãos públicos, mídia e a população, incitando críticas e questionamentos acerca do seu significado e função.

Essas intervenções podem ser coletivamente conceituadas como Grafismos Urbanos, entendidos como "qualquer expressão considerada artística ou não, produzida manualmente com o intuito de se passar mensagem e que possua como suporte a cidade" (RAMOS, 1994:13). Têm-se aqui maneiras particulares e criativas de comunicação executadas por artistas urbanos, baseadas em caligrafias próprias, riscos e desenhos, cujas finalidades e significados são modulados entre a expressão artística e a depredação dos suportes utilizados, oscilando segundo os interesses daqueles que recebem/leem essas mensagens. Dentro do amplo universo de grafismos urbanos, existe grande variedade de intervenções, algumas bem conhecidas como a pichação (o tipo de maior destaque em função do seu volume e ocorrência quase onipresente nas cidades brasileiras), o grafite, o lambe-lambe, ou o estêncil; enquanto outras formas são menos conhecidas como o grapixo e o bomb (ver Lewisohn, 2010 para uma discussão detalhada dos estilos e escolas).

No entanto, essas intervenções urbanas têm se ampliado e se diversificado, em que pese o conjunto de ações proibitivas à prática que vigeram em Belo Horizonte, sobretudo nos anos que antecederam à realização dos grandes eventos (Copa das Confederações, Copa do Mundo e alguns jogos de futebol dos Jogos Olímpicos do Rio de Janeiro), que coincidiram com as ações repressivas e higienistas capitaneadas pelo Prefeito Márcio Lacerda do PSB (Partido Socialista Brasileiro), que permaneceu no poder entre 2009 e 2016.

Com a intenção de estudar como se davam o posicionamento e a distribuição dos variados grafismos urbanos na cidade, Diniz et al (2015) promoveram uma catalogação e mapeamento das pichações encontradas no hipercentro de Belo Horizonte entre 2011 e 2012, revelando grandes assimetrias na distribuição espacial dessas intervenções. Os autores indicaram que os locais de maior visibilidade, como esquinas e vias de grande movimentação de veículos e circulação de pessoas, continham grande concentração de pichações, ao passo que em outras áreas da cidade essa forma de grafismo urbano era menos densa, quando não inexistente. Os autores apresentam uma hipótese interpretativa para esse descompasso espacial, sugerindo que certos recortes da cidade seriam "negligenciados ou evitados pelos pichadores, seja pela ausência de significado e valorização atribuídos pelos membros dessa prática, seja pelo vigilantismo aos quais esses locais estão expostos" (DINIZ et al, 2015, p.100.).

Por outro lado, Diniz et al (2017) exploraram os efeitos da indicação de Belo Horizonte como uma das sedes da Copa das Confederações de 2013 e Copa do Mundo de Futebol Masculino da FIFA em 2014 sobre a dinâmica da pichação no hipercentro da cidade. Os autores revelaram que o período que antecedeu a realização dos eventos foi caracterizado pela intensificação da repressão aos pichadores comandada pela Prefeitura Municipal de Belo Horizonte, que desenvolveu conjuntamente com os seus parceiros uma série de medidas restritivas à prática. Neste estudo, os pesquisadores reproduziram a catalogação e mapeamento das pichações encontradas no hipercentro de Belo Horizonte em 2015, revelando uma intensa disputa entre o poder público local e os pichadores pelo controle do território central da cidade, revelando, ainda, que apesar de toda a repressão o número de pichações havia ampliado entre 2011 e 2015. Por outro lado, em resposta à crescente repressão, os pichadores passaram a adotar suportes, posições nas edificações e materiais distintos, que privilegiavam formas mais ousadas e rápidas de pichação.

Desde que os dados que deram origem a esses estudos foram coletados, dois eventos marcantes podem ter influenciado a prática dos grafismos urbanos em Belo Horizonte, cujos efeitos merecem ser explorados. De um lado, observou-se a grande repercussão, de proporções internacionais, gerada pela implementação do programa "Cidade Linda" pela Prefeitura de São Paulo, em janeiro de 2017. Instituído no início do mandato do então prefeito João Doria do PSDB (Partido da Social Democracia Brasileira), o programa visava revitalizar as áreas degradadas da cidade, que contemplava, dentre outras ações, apagar os diversos grafites e pichações encontrados ao longo de grandes vias de circulação e outros pontos da cidade. A decisão gerou uma onda de protestos e ampla cobertura midiática, polarizando, uma vez mais, as opiniões. 
$\mathrm{Na}$ esteira desses protestos e de forma oportunista, o recém-empossado prefeito de Belo Horizonte, Alexandre Kalil do PHS (Partido Humanista da Solidariedade), anunciou no início de 2017 o Programa Profeta Gentileza. O programa visa fomentar e valorizar as artes visuais, especialmente a arte urbana, com o objetivo de apoiar os artistas de rua. Sob a coordenação da Fundação Municipal de Cultura, o Programa materializou importantes ações em 2017, com destaque para o "Primeiro Festival de Arte Urbana de Belo Horizonte", realizado na Av. Silva Lobo, no Bairro Grajaú (BELO HORIZONTE, 2018a); além de duas grandes intervenções de grafite na rua Silvianópolis, no bairro Santa Tereza, e no muro de contenção do viaduto Moçambique, no bairro Cachoeirinha (BELO HORIZONTE, 2018b).

Some-se a isso a divulgação em dezembro de 2017 do edital para a seleção de murais de arte urbana, segundo o qual a Prefeitura de Belo Horizonte, por meio da Secretaria Municipal de Cultura, selecionou propostas de murais artísticos, visando fortalecer e potencializar as manifestações artísticas no espaço público da cidade (BELO HORIZONTE, 2017). Paralelamente, Belo Horizonte recebeu a primeira edição do Circuito Urbano de Arte (Cura), no qual quatro edificações do hipercentro da cidade foram identificadas como objetos das intervenções, a partir do anglo de visão da Rua Sapucaí, no Bairro Floresta. A ideia era tornar a Rua Sapucai um mirante dos grafites promovidos pelo projeto, que contou com a participação de artistas mineiros, pernambucanos e da Espanha.

Mas não se pode esquecer que se o ambiente é extremamente favorável à prática do grafite, a pichação continua estigmatizada, tendo sido textualmente condenada pelo próprio prefeito Kalil (JORNAL ESTADO DE MINAS, 2017) e censurada por boa parte da população da cidade. Além disso, o município conta com significativo conjunto de leis que visam combater a prática. A Lei Municipal 6.995, de 22 de novembro de 1995, "proíbe a pichação no âmbito do município" (BELO HORIZONTE, 1995), ao passo que a Lei Municipal 10.059, de 2010 instituiu a Política Municipal Antipichação com o objetivo de conter a poluição visual e criar estratégias para combatê-la, de modo a "recuperar e promover a qualidade visual do ambiente urbano"; e "conscientizar os cidadãos dos malefícios que a prática da pichação traz à coletividade" (BELO HORIZONTE, 2010). Mais recentemente, a Lei Municipal 10.931, de junho de 2016, institui política contra a prática da pichação, definindo que os estabelecimentos que comercializam tintas em sprays, realizem e mantenham um cadastro dos compradores por pelo menos três anos (BELO HORIZONTE, 2016).

Diante deste quadro, a pergunta que orienta o presente estudo é: em que medida a mudança no comando da Prefeitura de Belo Horizonte, com a chegada de Alexandre Kalil do PHS, e a manutenção da legislação municipal flagrantemente contrária à pichação, pode ter impactado os grafismos urbanos na cidade? Para tal realizamos uma replicação da metodologia de catalogação e mapeamento dos grafismos urbanos adotadas por Diniz et al (2015) e Diniz et al (2017), buscando entender como evoluíram a distribuição espacial, estilos e práticas associadas a esses grafismos no hipercentro da cidade.

\section{TERRITÓRIOS SIMBÓLICOS E FUNCIONAIS}

O espaço urbano é um organismo vivo e complexo, onde múltiplas dimensões se integram e se articulam estabelecendo formas, contornos, relações e vivências diversas. Este espaço não é apropriado por todos de igual modo, sendo as vivências urbanas individuais consumadas nos movimentos e pausas realizadas fora do ambiente doméstico (SILVA, 2008), constituindo o espaço representacional (LEFEBVRE, 1996) da experiência do dia a dia, com todas as interações dele decorrentes. Parafraseando Miles (1997), tratam-se dos espaços vividos e sentidos da vida cotidiana, envolvendo comunicações não verbais, apropriações, rituais, mercados, trânsito e outros aspectos da vida na rua.

Este espaço, por sua vez, é apropriado segundo distintas lógicas, conotando múltiplos significados. Para além da cidade formal, controlada pelo poder público, que exerce o seu controle por meio de leis que organizam e definem o espaço urbano, tem-se a cidade criada e recriada pelas ações dos grupos sociais, que também se apropriam desses mesmos espaços de forma diversa: por meio de intervenções gráficas. "É questão de escala: por debaixo dos mapas, das leis e dos planejamentos há um sem fim de cidades acontecendo simultaneamente. Há diversas outras estéticas e outros espaços escondidos sobre as 
superfícies urbanas." (SOARES 2016, p.61). Reforçando este aspecto do espaço urbano, Brandão e Schmidt (2008, p. 2) constatam que o processo de reflexão dos contrastes inerentes ao espaço urbano passa necessariamente pela compreensão das "várias capas da paisagem urbana", visto que a cidade é um ente coletivo, um espaço de intercâmbios, que expressa a ideia de cidadania da comunidade".

Nesta junção, os artistas de rua, agentes responsáveis pelos grafismos urbanos, ganham protagonismo. O processo de construção das ubíquas marcas deixadas na paisagem urbana é pautado na experiência geográfica dos artistas de rua; no modo como percebem e selecionam os suportes nos quais imprimem as suas intervenções. Esta experiência geográfica, por sua vez, encontra-se associada à noção de "geograficidade", que representa a condição espacial da existência do ser humano, a essência geográfica do ser e do estar no mundo (DARDEL, 2011). Ou ainda como colocado por AMORIM FILHO (1999), a "geograficidade" ou (géographicité), seria forjada a partir das ligações experienciais que apoiam os laços das pessoas com os lugares, regiões, paisagens, mobilidades e natureza.

A geograficidade, por sua vez, resulta em um modo de comunicação cuja experienciação do ser no espaço tece a ligação concreta entre ser humano e suporte, e, como consequência, a ativação de lugares "acionados por atores sociais em suas interações e comunicações quotidianas" ou ainda, "como a experiência e a imaginação humanas se apropriam das características e qualidades físico-materiais da localização geográfica” (SOUZA, 2013, p.113). Junto a este processo ocorrem normatizações que definem a criação de territórios simbólicos no espaço urbano, que "mantêm formas de controle", de "normatização de usos, de atitudes e comportamentos", contestados pela resistência e mobilização sociais, nas quais se manifestam a dimensão reativa e a inventividade dos sujeitos" (GOMES. 2002 p.12).

Por sua vez, o território não é feito de poeira cósmica, mas construído a partir do espaço constituindo-se resultado de uma apropriação concreta ou abstrata. No processo de construção de territórios, os atores realizam no espaço um trabalho, isto é, projetam sobre ele energia e informação, adaptando-o às necessidades dos atores territorializadores (RAFFESTIN, 1993, 2008). Esses agem sobre o espaço (natural e social) de forma objetiva e/ou subjetiva, formulando territórios entendidos como espaços naturais, sociais, historicamente organizados e produzidos, sendo a paisagem o aspecto visível e percebido deste processo. Em outras palavras, "o território é produto de ações históricas que se concretizam em momentos distintos e sobrepostos, gerando diferentes paisagens" (SAQUET, 2008: 81), sendo, portanto, um espaço "definido e delimitado por e a partir de relações de poder" (SOUZA, 1995:78).

Como os territórios são antes de tudo fruto de relações sociais projetadas no espaço, esses podem apresentar natureza efêmera, formando-se e dissipando-se rapidamente, ao sabor da intensidade, natureza e regularidade das relações sociais por ele engendradas (SOUZA, 1995). Trata-se de aspecto extremamente relevante à discussão dos voláteis territórios forjados pelos artistas de rua, que disputam com outros atores urbanos o domínio sobre uma paisagem urbana viva e em constante mutação.

Dada à complexidade de atores e relações sociais projetadas no espaço, pode-se deparar com a condição na qual territórios superpostos se desenvolvem, seja em caráter transitório, cíclico, errático ou permanente sobre um mesmo espaço. Trata-se de atributo precioso ao exame das territorialidades dos artistas de rua, que com os seus antagonismos internos e grupos rivais, comandam, em associação explícita ou tácita com outros atores sociais, a apropriação do espaço do hipercentro de Belo Horizonte.

Em que pese o território ser definido inicialmente por sua dimensão política, aspectos culturais, tais como o simbolismo, teias de significados e identidades são igualmente caros ao processo 
de construção e manutenção dos territórios (SOUZA, 1995). O território como espaço concreto em si é apropriado ou ocupado por um grupo social, gerando raízes e identidade, não sendo possível compreender uma determinada coletividade (ex: artistas de rua) dissociada do seu território. Como pensar os artistas de rua desvinculados dos atributos físicos do espaço urbano (patrimônio arquitetônico, equipamentos, paisagem, etc.). Portanto, o território define um limite e uma alteridade, estabelecendo uma diferença entre os membros de determinada coletividade e aqueles estranhos a ela, revestindo-se de caráter identitário e simbólico.

Esta faceta simbólica e identitária do território é ressaltada por Haesbaert (2008), que sugere a existência de uma gradação na articulação territorial, oscilando desde territórios com maior carga funcional e material, até aqueles com maior carga simbólica. Segundo o autor, não são concebíveis territórios exclusivamente funcionais, uma vez que sempre haverá neles contida uma dimensão simbólica, tampouco territórios exclusivamente simbólicos, uma vez que o espaço material estará inevitavelmente ali presente.

Santos reforça a dimensão simbólica do território afirmando que o: "território não é apenas o resultado da superposição de um conjunto de sistemas naturais e um conjunto de sistemas de coisas criadas pelo homem. O território é o chão e mais a população, isto é, uma identidade, o fato e o sentimento de pertencer àquilo que nos pertence. O território é a base do trabalho, da residência, das trocas materiais e espirituais e da vida, sobre os quais ele influi" (SANTOS, 2002, p.96).

Medeiros (2008) confirma a condição existencial do território, concebendo-o como um espaço de identidade; um espaço cultural de identificação ou de pertencimento. A autora entende o território como uma "parcela do espaço enraizada numa mesma identidade e que reúne indivíduos com o mesmo sentimento", sendo que os traços que delimitam o território marcam o "espaço de sobrevivência" e "o espaço de força". Neste sentido, o território é este o "espaço defendido, negociado, cobiçado, perdido, sonhado cuja força afetiva e simbólica é forte" (MEDEIROS, 2008: 218).

A dualidade entre as dimensões funcional e simbólica do território exortou Serpa (2017) a oferecer uma estimulante observação sobre a relação entre os conceitos de lugar e território, que remetem a experiências geográficas que por vezes se confundem, se interpenetrando. Serpa (2017) questiona se o exercício do poder seria possível sem a vivência do espaço, bem como se o espaço vivido não estaria de alguma forma subordinado ao exercício do poder. Trata-se de noção preciosa ao escrutínio da ação dos artistas de rua no hipercentro de Belo Horizonte, uma vez que esses indivíduos ao reivindicarem o seu direito à cidade por meio de suas intervenções nas fachadas de edificações e equipamentos urbanos, reterritorializam esses espaços, reforçando, ainda, identidades coletivas ou individuais. Portanto, é com base nessas perspectivas e abordagens que passamos a examinar a evolução dos grafismos urbanos no hipercentro de Belo Horizonte entre 2011 e 2017.

\section{EVOLUÇÃO DOS GRAFISMOS URBANOS NO HIPERCENTRO DE BELO HORIZONTE}

A lei municipal № 7166 de 1996, que estabeleceu as Normas e Condições para o Parcelamento, Ocupação e Uso do Solo Urbano no Município de Belo Horizonte, organizou a área urbana em zonas de acordo com as diretrizes emanadas do Plano Diretor. Essas zonas, por sua vez, são diferenciadas segundo os potenciais de adensamento e as demandas de preservação e proteção ambiental, histórica, cultural, arqueológica ou paisagística. Dentre essas zonas, interessam a esta pesquisa as ZCs (Zonas Centrais), consideradas regiões configuradas como centros de polarização regional, municipal ou metropolitana, subdivididas em ZCBH - Zona Central de Belo Horizonte; ZCBA - Zona Central do Barreiro; ZCVN - Zona 
Central de Venda Nova; e ZHIP - Zona Hipercentral, que é o recorte geográfico adotado como referência para o presente artigo (BELO HORIZONTE, 1996) (ver figura 1).

Figura 1 - Mapa de Localização do hipercentro de Belo Horizonte.

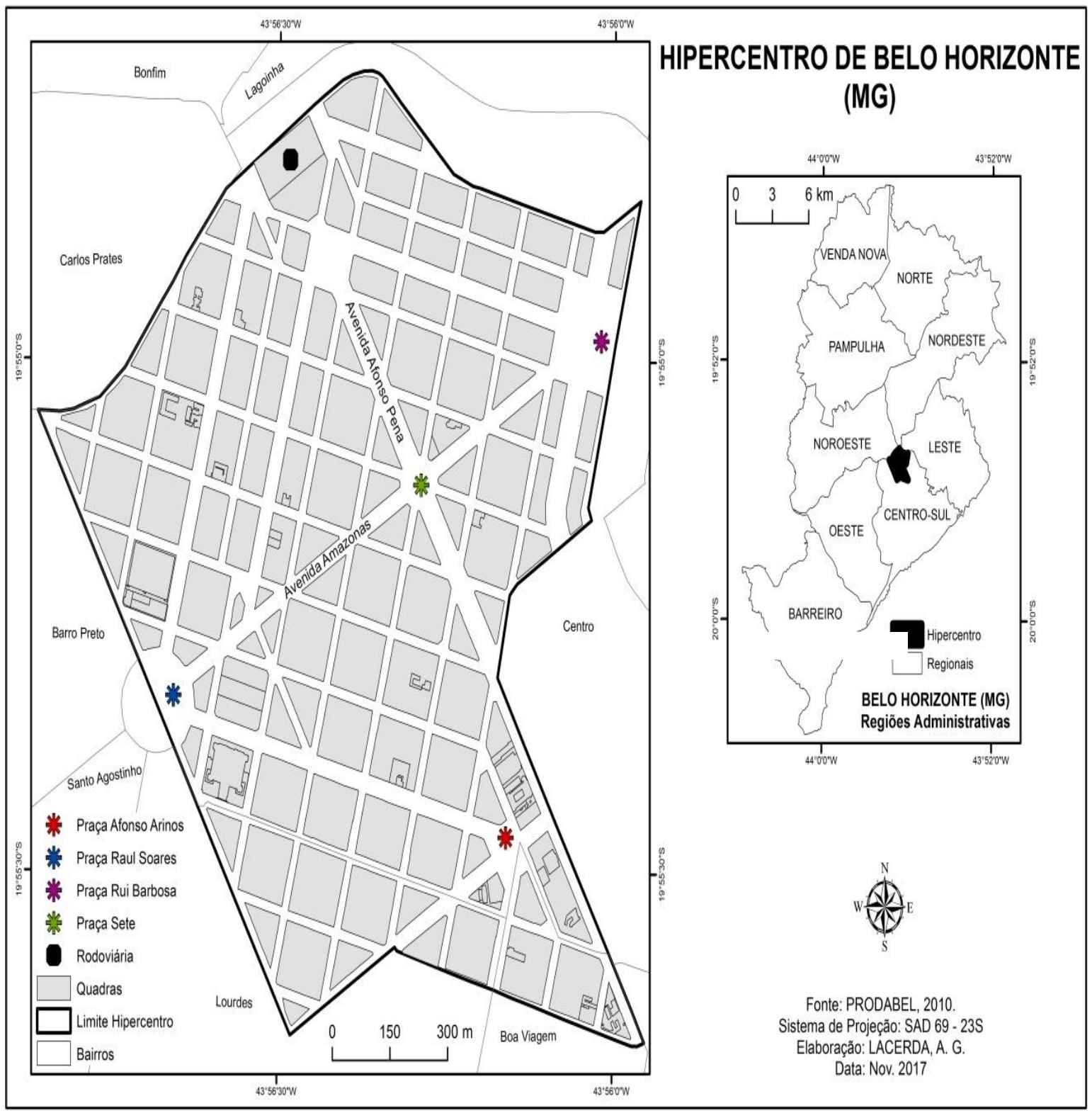

A história do hipercentro de Belo Horizonte se confunde com a própria história da cidade, sendo o seu contorno integralmente inserido no plano de Aarão Reis, que foi inspirado por ideais positivistas, adotando uma disposição diagonal das ruas. Originalmente planejada para abrigar uma população em torno de 200.000 habitantes, a cidade encontrava-se circunscrita por uma avenida que fazia o seu contorno, demarcando o limite entre as zonas urbana e suburbana. A nova capital foi inaugurada em 12 de dezembro de 1897, sendo que ainda hoje vários espaços e edifícios construídos na época da inauguração encontram-se preservados (Praça da Liberdade, Parque Municipal Américo Renée Gianetti, Praça da Estação, por exemplo), elementos esses inseridos no Hipercentro da cidade. Por esta razão o número de imóveis tombados é grande na área, constituindo-se importante referência para o patrimônio histórico cultural local (BARRETO, 1996).

O Hipercentro também congrega diversos serviços de uso coletivo, cuja polarização transborda os limites do município de Belo Horizonte, abarcando a sua Região Metropolitana. Destacamse aqui as concentrações de equipamentos de saúde, financeiros, entretenimento, cultura e 
administração pública, que garantem ao Hipercentro grande circularidade de pessoas ao longo de todos os dias da semana, incluindo o período noturno, quando vários desses equipamentos encontram-se em operação. Sublinhe-se, ainda, o grande número de espaços públicos que são intensamente utilizados pela população, como parques e praças, mas também as feiras que ali se realizam regularmente. Outro aspecto importante diz respeito às condições de circulação, marcadas por tráfego intenso e por constituir-se um grande nó articulador do sistema viário radial da cidade de Belo Horizonte, aspecto que conjugado com a diversidade de formas de uso apontada anteriormente, faz com que a sua população flutuante do Hipercentro chegue a mais de 1 milhão de pessoas dia (CÂMARA DE DIRETORES LOJISTAS DE BELO HORIZONTE, 2017).

Também é forte a presença de imóveis de uso residencial no Hipercentro, que congregam moradores com perfil peculiar, que se diferencia não apenas do conjunto do município, mas também da região na qual se encontra inserido (Centro-Sul). Trata-se de população mais envelhecida, com idade média em torno de 40 anos e o predomínio do contingente feminino, especialmente nos estratos etários superiores a 30 anos. O Hipercentro também se distingue do restante da cidade no quesito escolaridade, sendo a proporção de responsáveis por domicílios com 11 anos ou mais de estudos superior àquele encontrado na regional Centro-Sul e no conjunto de Belo Horizonte; também se destacando em relação ao padrão de rendimentos médios. Cabe destacar que existe uma distribuição assimétrica das formas de uso na área do hipercentro, encontrando-se as edificações de uso residencial mais concentradas na porção sul e oeste, como demonstra o diagnóstico produzido por Belo Horizonte (2007).

Em virtude dessas características, é natural que o Hipercentro seja uma área bastante visada pelos artistas de rua, dada à grande e imediata notoriedade que os grafismos urbanos ali presentes apresentam (ISNARDIS 1997). Por essa razão, este recorte do município de Belo Horizonte foi eleito como área de estudo.

O processo de levantamento de dados foi baseado em um formulário que orientou o registro de diversas informações acerca dos grafismos urbanos presentes no Hipercentro, com destaque para a natureza da edificação utilizada como suporte para o grafismo, posição adotada na edificação, estilo do grafismo, instrumentos empregados em sua construção e tipos de mensagens veiculadas. Uma vez preenchidos os formulários específicos para cada grafismo urbano, as intervenções urbanas foram fotografadas e com o auxílio do cadastro de endereços da Prefeitura Municipal de Belo Horizonte a sua posição geográfica foi registrada.

Dadas as especificidades do Hipercentro de Belo Horizonte, o levantamento de dados foi realizado em distintas etapas. A equipe de campo percorreu diligentemente cada quarteirão da área de estudos ao longo dos dias úteis e retornou aos mesmos quarteirões nos fins de semana. Afinal, diversos grafismos urbanos encontravam-se escamoteados pela intensa atividade comercial, só sendo passiveis de registro sistemático aos fins de semana, especialmente aquelas intervenções realizadas sobre as portas dos estabelecimentos comerciais.

Findada a fase da coleta, os formulários foram digitalizados e compuseram um banco de dados que serviu de base para as análises estatísticas e espaciais aqui apresentadas. Estatísticas descritivas foram geradas com base nesses dados, de modo a sintetizar as informações relativas ao conjunto de grafismos urbanos. Por outro lado, produziram-se mapas híbridos que, além de indicar a posição geográfica dessas intervenções, também revelam a sua densidade nos quarteirões do Hipercentro, apresentando, portanto, uma implantação pontual e coroplética simultaneamente.

Esses procedimentos foram adotados na catalogação dos grafismos urbanos em 2011, 2015 e 2017, revelando que o espaço do Hipercentro de Belo Horizonte vem sendo disputado por atores hegemônicos e hegemonizados, gerando territórios efêmeros e paisagens transientes.

A figura 2 evidencia a natureza mutante desta manifestação espacial na área de estudos, indicando significativa oscilação no número de grafismos urbanos ali encontrados. Respondendo aos estímulos emanados dos atores hegemônicos da cidade e suas intervenções higienistas nas edificações e equipamentos urbanos, nota-se que o número de grafismos urbanos aumentou entre 2011 e 2015, sofrendo uma sensível redução em 2017. Em 2015 contabilizou-se 2.998 intervenções na área de estudo, que passaram a ser $2.884 \mathrm{em}$ 2017, uma redução em 3,9\% (figura 2). É possível, ainda, notar a redução no número total de

$\begin{array}{llllll}\text { Caminhos de Geografia } & \text { Uberlândia-MG } & \text { v. 20, n. 71 } & \text { Setembro/2019 } & \text { p.85-103 } & \text { Página } 91\end{array}$


grafismos com a explícita intencionalidade de demarcação territorial. Entretanto, percebe-se um leve aumento das intervenções de cunho político e crescimento de outros tipos de grafismo, como frases poéticas entre outras.

Figura 2 - Número e natureza dos grafismos urbanos no Hipercentro de Belo Horizonte.

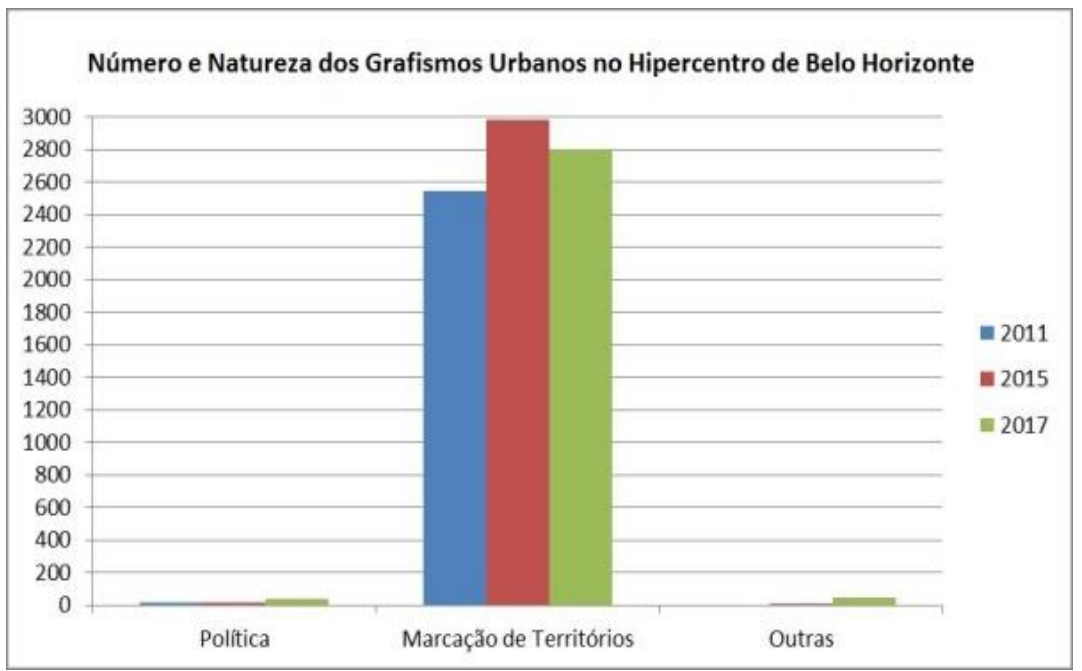

Fonte - Dados da pesquisa 2011, 2015, 2017.

As edificações permanecem sendo o principal alvo dos artistas urbanos $(98,4 \%)$, sendo os monumentos e equipamentos menos utilizados como suporte para as suas intervenções ao longo do período analisado (figura 3).

Figura 3 - Suporte empregado pelos grafismos urbanos no Hipercentro de Belo Horizonte

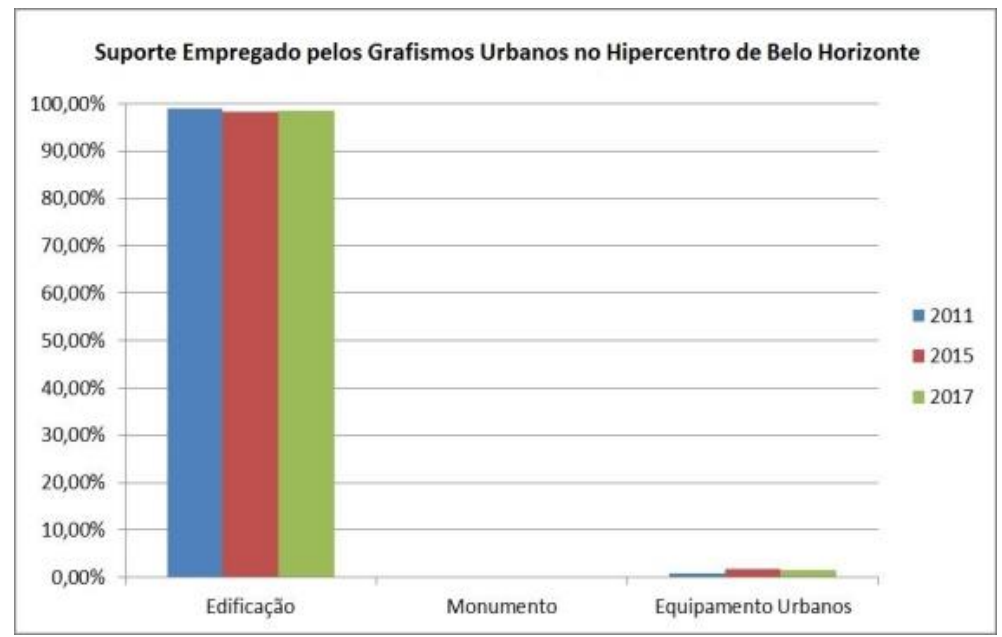

Fonte - Dados da pesquisa 2011, 2015, 2017.

Quando se leva em consideração o tipo de edificação empregada como suporte para os grafismos urbanos, percebe-se uma importante e consistente tendência no período analisado, que indica a preponderância dos prédios comerciais (figura 4). Este predomínio é resultante da maior oferta de imóveis comerciais dada à funcionalidade urbana predominante no Hipercentro de Belo Horizonte, coincidente com o CBD da cidade. Destaque-se em patamar inferior, mas com tendência de expansão, os prédios residenciais e os estacionamentos privados. Essa concentração secundária se dá em virtude das especificidades do Hipercentro de Belo Horizonte, que apresenta formas de uso misto, com forte presença de unidades residenciais, 
em meio à oferta de bens e serviços. Além disso, dado o fluxo intenso de veículos e as restrições relativas ao estacionamento público nas vias que cortam a área, tem sido crescente a oferta de espaços privados de estacionamento. Por outro lado, o número de grafismos urbanos presentes nos prédios públicos e desocupados é decrescente. Este resultado pode ser explicado, pelo menos parcialmente, pela crescente repressão e vigilância associada às edificações públicas em relação aos artistas urbanos, fato que tem promovido a migração para outros tipos de prédios no Hipercentro. Por fim, cabe destacar que a diminuição do número de intervenções em prédios desocupados está relacionada à retomada de várias construções que se encontravam suspensas por motivos variados.

Figura 4 - Tipo de Edificação Empregada como Suporte pelos Grafismos Urbanos no Hipercentro de Belo Horizonte.

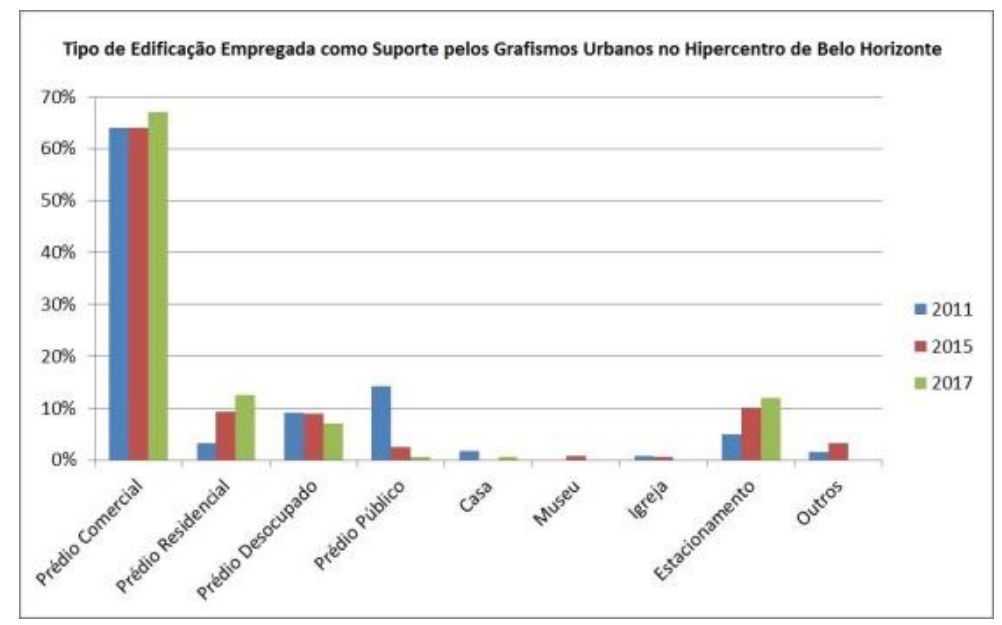

Fonte - Dados da pesquisa 2011, 2015, 2017.

Dentre as partes das edificações mais buscadas pelos artistas de rua destacam-se os muros (93,8\% em 2011; 78,3\% em 2015; e 67\% em 2017) (figura 5). No entanto, nota-se a continuidade de uma tendência apontada por Diniz et al (2017) de ampliação da proporção de grafismos urbanos sobre portas de loja e janelas em virtude da crescente intolerância da comunidade belo-horizontina em relação aos artistas de rua. Portanto, em resposta à intransigência e à repressão, os artistas passaram operar fora dos horários de funcionamento dos prédios comerciais, adotando de forma crescente as portas e janelas como suportes para as suas intervenções (figura 5).

Figura 5 - Aspecto da Edificação Empregado como Suporte pelos Grafismos Urbanos no Hipercentro de Belo Horizonte.

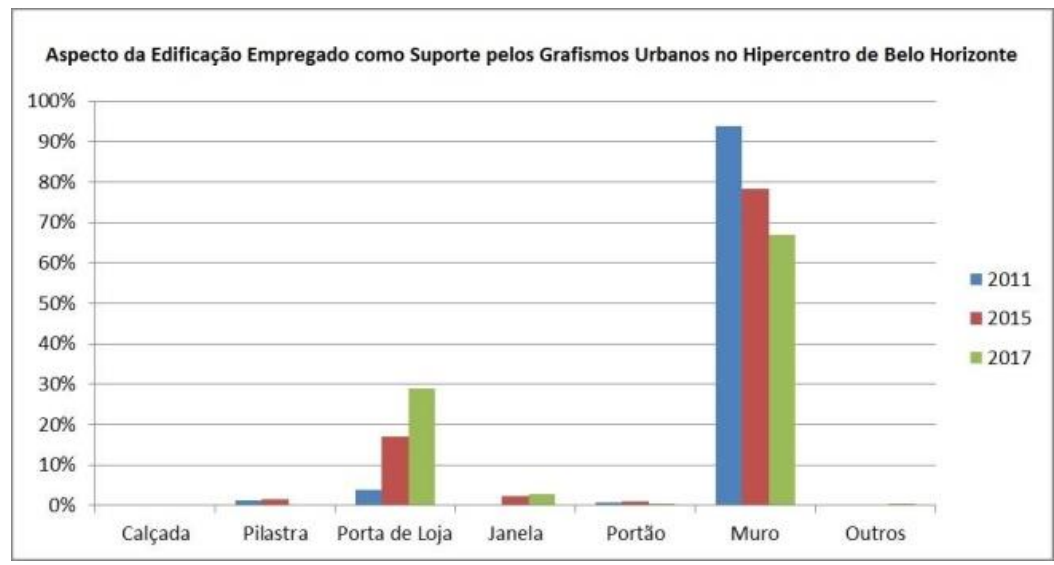

Fonte - Dados da pesquisa 2011, 2015, 2017. 
Outra tendência observada por Diniz et al (2017) que se manteve em 2017 foi a forte e crescente concentração dos grafismos urbanos posicionados nas edificações no nível do olhar dos transeuntes; acompanhada da redução das intervenções nas marquises dos prédios. Como os autores apontavam no estudo publicado em 2017, observa-se mais uma mudança comportamental na ação dos artistas de rua em face à crescente repressão, fazendo com que passassem a adotar condutas mais defensivas, como, por exemplo, realizar intervenções em locais que facilitam a evasão (figura 6). Porém, nota-se relativa manutenção no número de intervenções no topo das edificações ao longo do período analisado, fato que pode ser explicado parcialmente pela dificuldade de acesso a esses locais, tanto por artistas de rua, quanto por proprietários ou gestores comprometidos com a remoção dessas intervenções, processos que se combinam perenizando os grafismos urbanos encontrados nesses locais.

Figura 6 - Posição na Edificação Empregada como Suporte pelos Grafismos Urbanos no Hipercentro de Belo Horizonte.

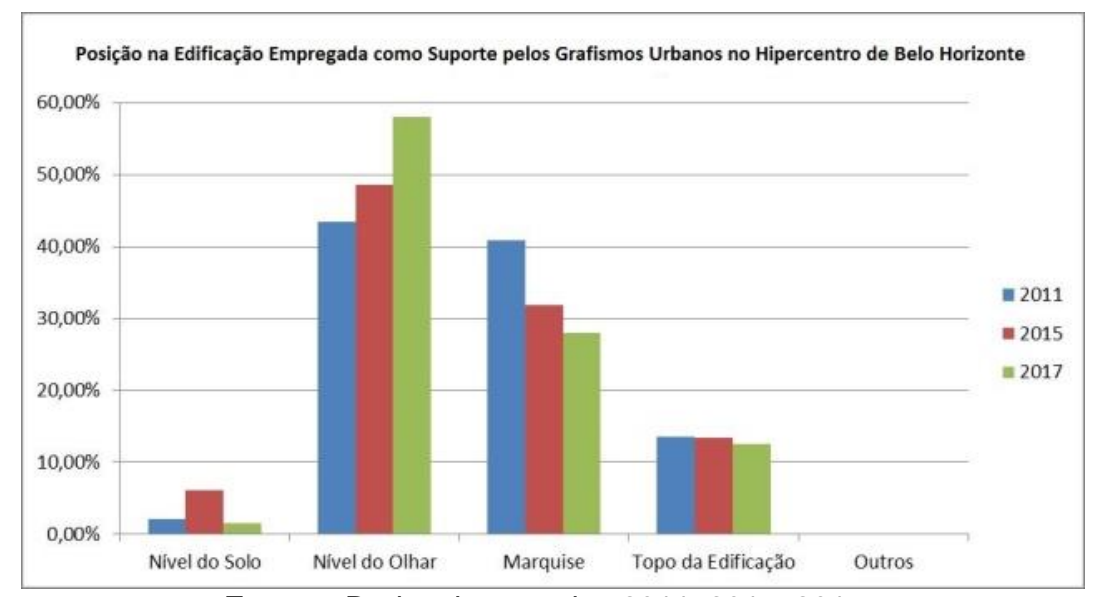

Fonte - Dados da pesquisa 2011, 2015, 2017.

Diversos são os materiais utilizados na elaboração dos grafismos urbanos, porém como observado em anos anteriores, o spray aerossol continua dominando a preferência dos artistas de rua (figura 7), por ser material relativamente fácil de ser aplicado e transportado e, sobretudo, dissimulado diante de abordagens repressivas por parte de policiais e agentes privados de segurança. O rolinho continua a perder adeptos, mas outro fato que chama a atenção é o aumento na utilização do borrifador (passando de 0,9\% em 2015 para 3,6\% em 2017), por ser instrumento mais facilmente transportado, ocultado e mais prático de ser utilizado nas partes mais altas das edificações do que o rolinho.

Figura 7 - Material Empregado na Produção dos Grafismos urbanos no Hipercentro de Belo Horizonte. 


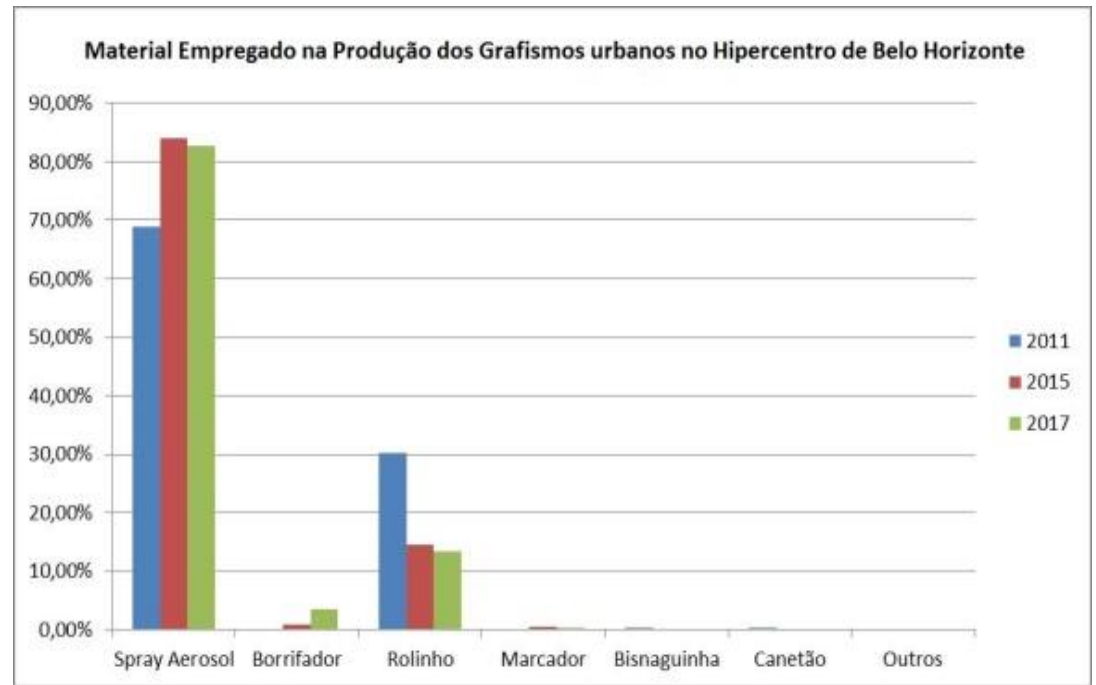

Fonte - Dados da pesquisa 2011, 2015, 2017.

Dentre as diversas formas de grafismos urbanos, destacam-se as pichações nos estilos carioca, paulista e mineiro (figura 8). A figura 9 evidencia a presença expressiva da pichação paulista no território belo-horizontino, sendo a pichação mineira menos contabilizada (figura 9). A paulista passa de $25,3 \%$ para $44,6 \%$ entre 2015 e 2017 , enquanto a mineira cai de $71,6 \%$ para $43,5 \%$. Isto se deve, provavelmente, à projeção que a pichação paulista vem tendo na mídia alternativa e à crescente visibilidade dos seus artistas, fato que tem influenciado no estilo adotado pelos pichadores de Belo Horizonte.

Percebe-se também a crescente presença de grapixos e bombs (figura 8), que por serem mais coloridos e elaborados são confundidos com o grafite - prática muito mais aceita pelo poder público e pela população do que a pichação, como pode ser comprovado na parte introdutória deste trabalho. Nota-se, portanto, mais uma evidência da mudança comportamental adotada pelos artistas de rua de Belo Horizonte na busca pelo direito de se expressar livremente na cidade. Cabe, ainda, sublinhar a ampliação das "outras" formas de arte de rua, dentre as quais se encontram o grafite, o lambe-lambe e o estêncil, fomentadas pelas políticas de incentivo da Prefeitura Municipal de Belo Horizonte assinaladas na introdução deste artigo.

Figura 8 - Tipos de grafismos urbanos.

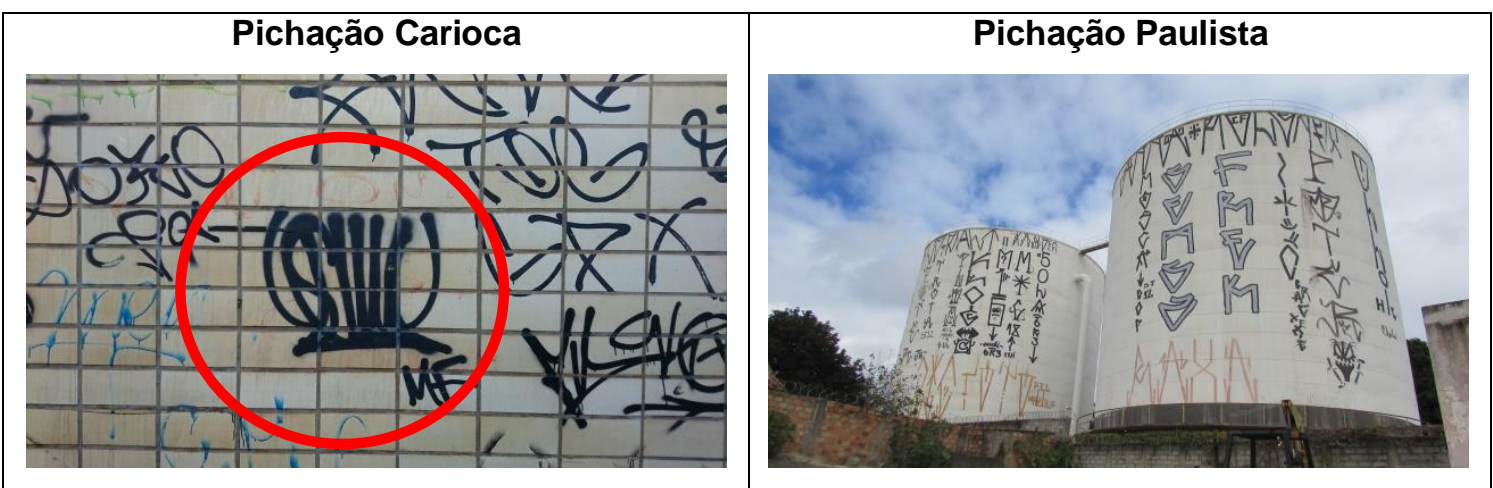




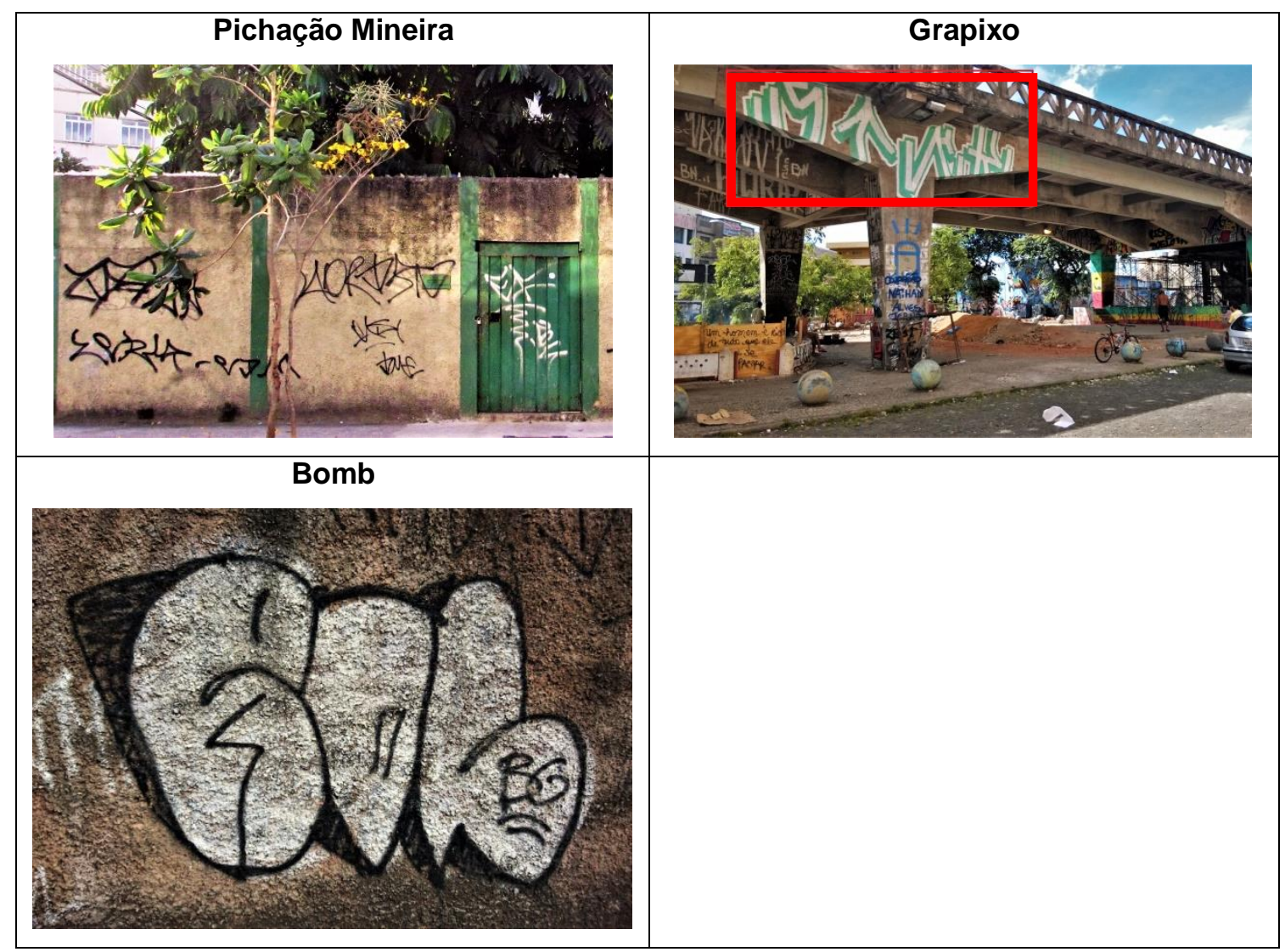

Fonte - FERREIRA, R.G.B. (2018). 
Figura 9 - Tipo de Grafismos Urbanos encontrados no Hipercentro de Belo Horizonte.

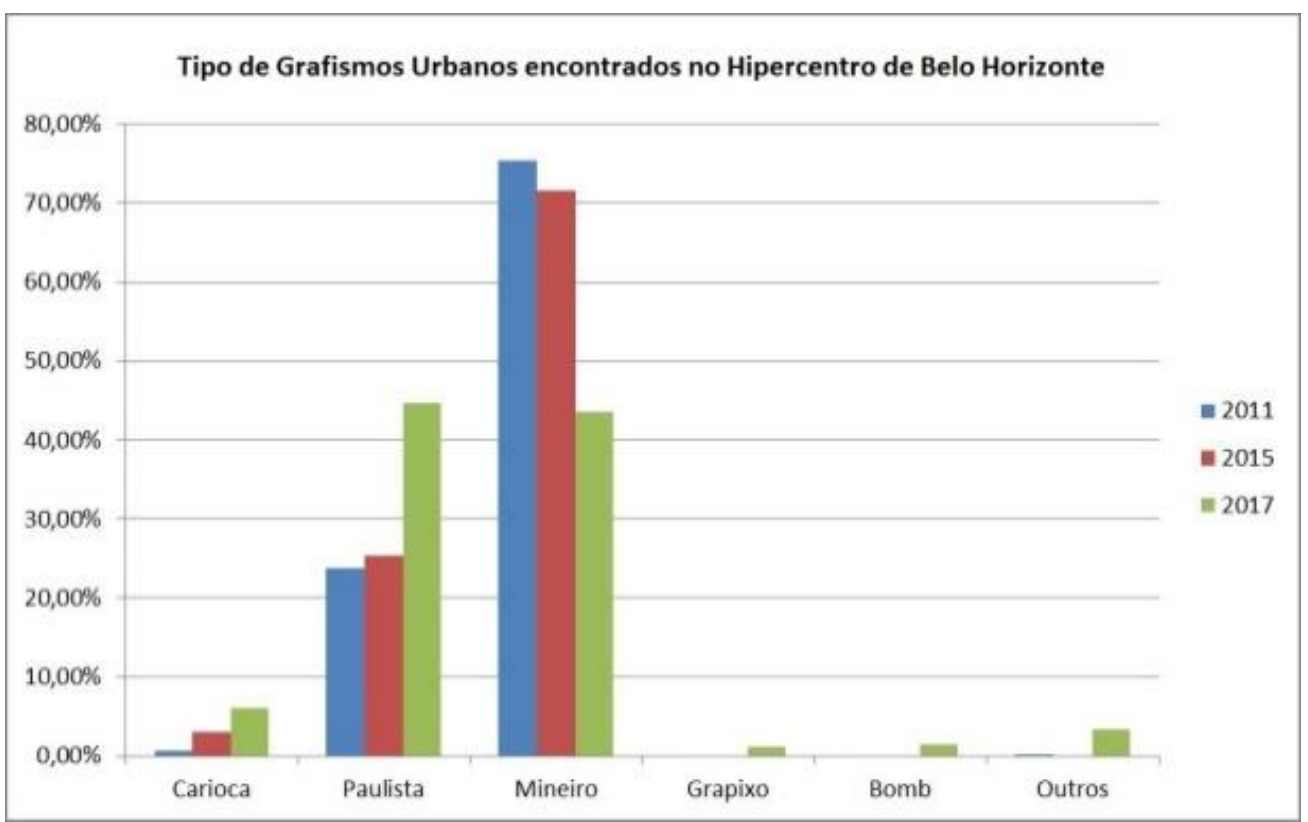

Fonte - Dados da pesquisa 2011, 2015, 2017.

A demarcação territorial por meio dos grafismos urbanos pode-se dar de maneira coletiva, quando um grupo de artistas, organizados ou não em bondes, se apropriam coletivamente das fachadas de edificações, ou, ainda, de forma individual. Neste caso, pode-se falar da construção de microterritorialidades pautadas na aplicação da marca ou tag do indivíduo sobre a parte da fachada de uma edificação. O local sobre o qual o grafismo urbano é aplicado se torna um microterritório vertical, não devendo este ser "atropelado" (gíria empregada entre os artistas de rua) ou sobrescrito por outro artista, sendo esse ato interpretado como ultrajante ofensa - uma declaração de guerra, que tem como resposta "contra-atropelos", discussões, quando os contentores não saem às vias de fato de modo a pacificar o agravo.

O Hipercentro de Belo Horizonte é testemunha da extensão deste aspecto do código de comportamento dos artistas de rua, sendo raros os casos em que foi possível identificar sobreposições de grafismos urbanos (figura 10).

Figura 10 - Grafismos Urbanos com e sem superposição no Hipercentro de Belo Horizonte.

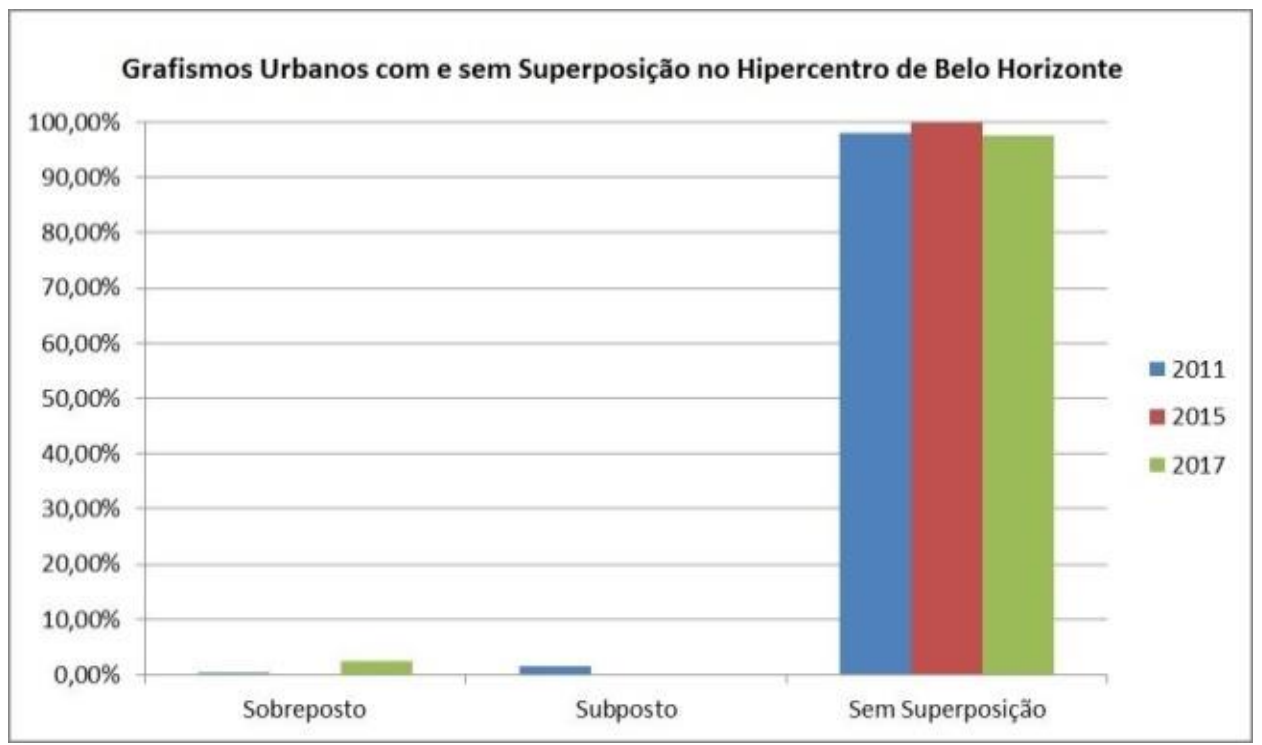

Fonte - Dados da pesquisa 2011, 2015, 2017. 
Os raros eventos em que sobreposições foram constatadas se deram quando pichações antigas, já bastantes deterioradas pelo tempo, portanto, quase invisíveis, foram sobrepostas por intervenções mais recentes. Neste caso observa-se uma micro-territorialização, que ajuda a dinamizar a paisagem e as relações de poder no espaço urbano.

O exame da evolução espacial da ação dos artistas de rua no Hipercentro de Belo Horizonte indica o quão dinâmico e transiente é a paisagem urbana e o quão efêmero são as territorialidades por eles comandadas (ver figuras 11a,b,c). Mas em meio à aparente desordem espacial, existem algumas consistências que gostaríamos de pontuar. Primeiramente, cabe apontar a consistente e crescente incidência de grafismos na porção nordeste do hipercentro, em uma área predominantemente dominada por edificações devotadas às atividades comerciais e prestadoras de serviço e onde se encontra o principal ponto de referência da cidade da cultura Hip-Hop: as proximidades do viaduto Santa Tereza, onde vários eventos culturais ligados à cena, como o Duelo de MCs vem acontecendo, congregando grande número de artistas de rua.

Figura 11a - Distribuição espacial dos grafismos urbanos no hipercentro de Belo Horizonte em 2011.

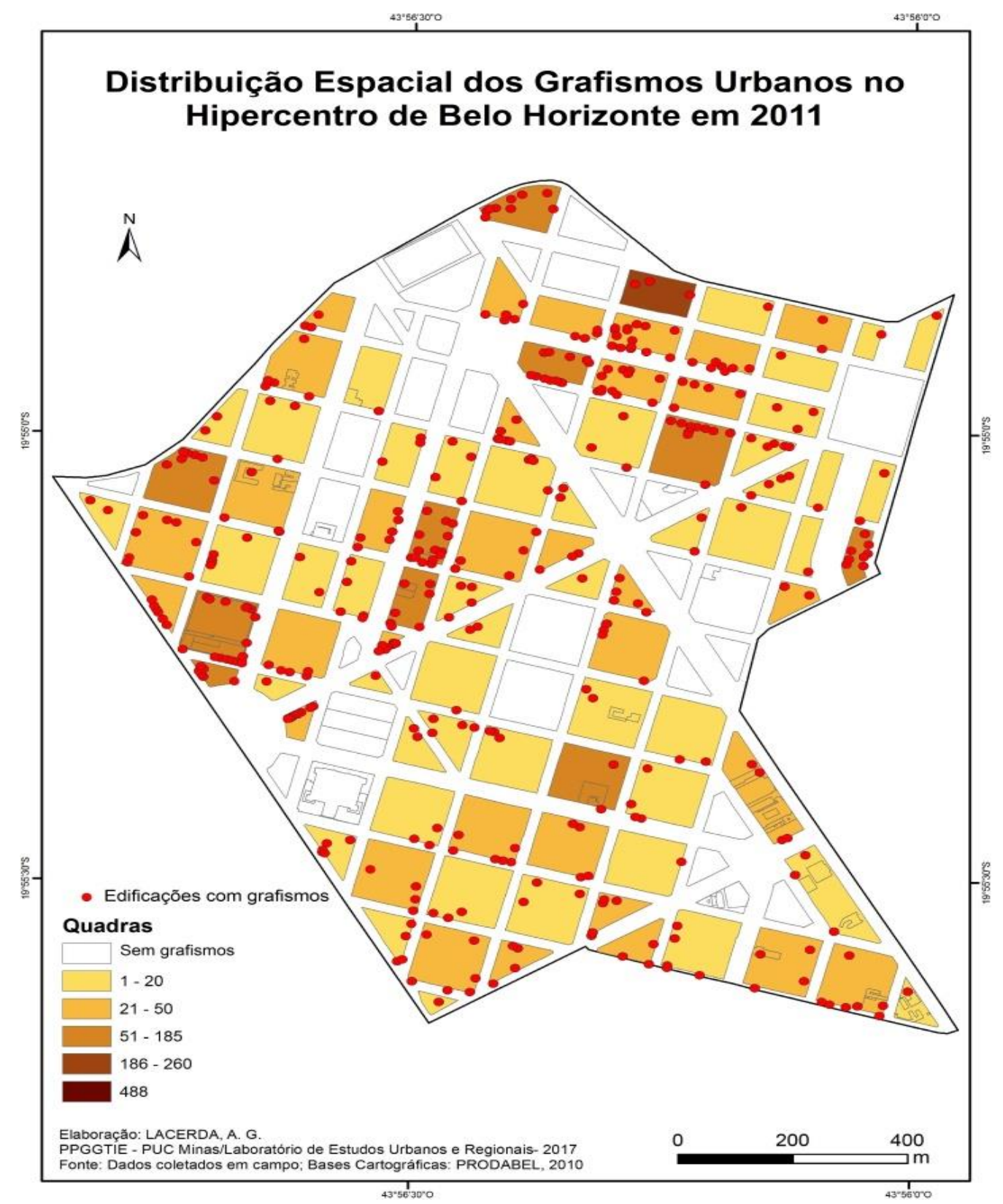


Figura 11b - Distribuição espacial dos grafismos urbanos no hipercentro de Belo Horizonte em 2015.

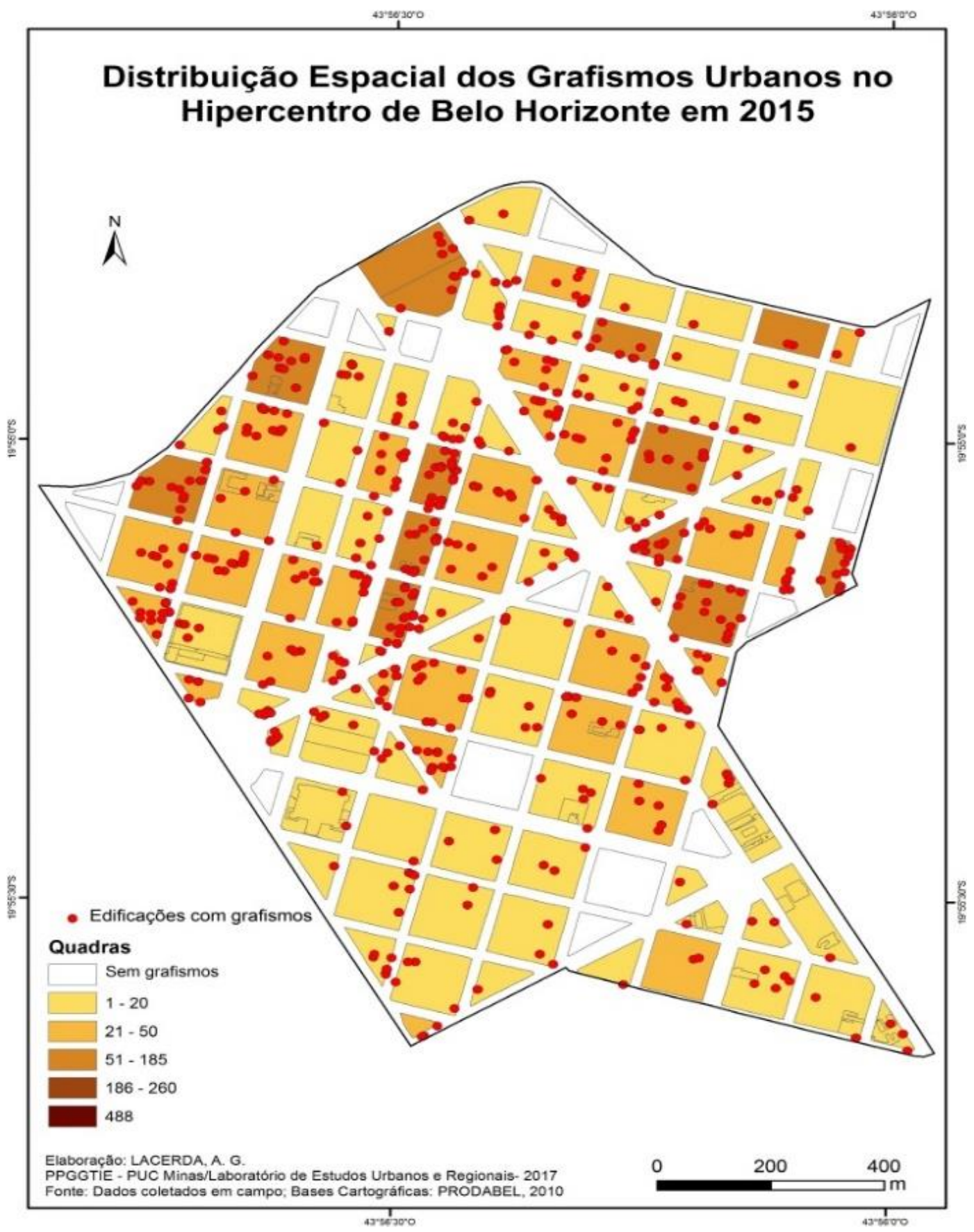

Uma concentração secundária se faz evidente no quadrante noroeste do Hipercentro, onde as funções comerciais estão mais agrupadas. Trata-se de uma área que se estende a partir da Rodoviária Municipal de Belo Horizonte e por onde circulam e têm pontos de parada algumas das principais linhas do BRT (Bus Rapid Transit) que serve à cidade; uma área caracterizada por grande circulação de pessoas, portanto, muito cobiçada pelos artistas de rua. Destaquese, ainda, o número sensivelmente menor de grafismos na porção sudoeste. Trata-se da parte do hipercentro onde se encontram mais densamente presentes as edificações residenciais, portanto, onde existe uma maior vigilância e presença de pessoas diuturnamente. Há, portanto, uma clara geografia na manifestação dos artistas de rua que operam no Hipercentro de Belo Horizonte. 
Figura 11c - Distribuição espacial dos grafismos urbanos no hipercentro de Belo Horizonte em 2017.

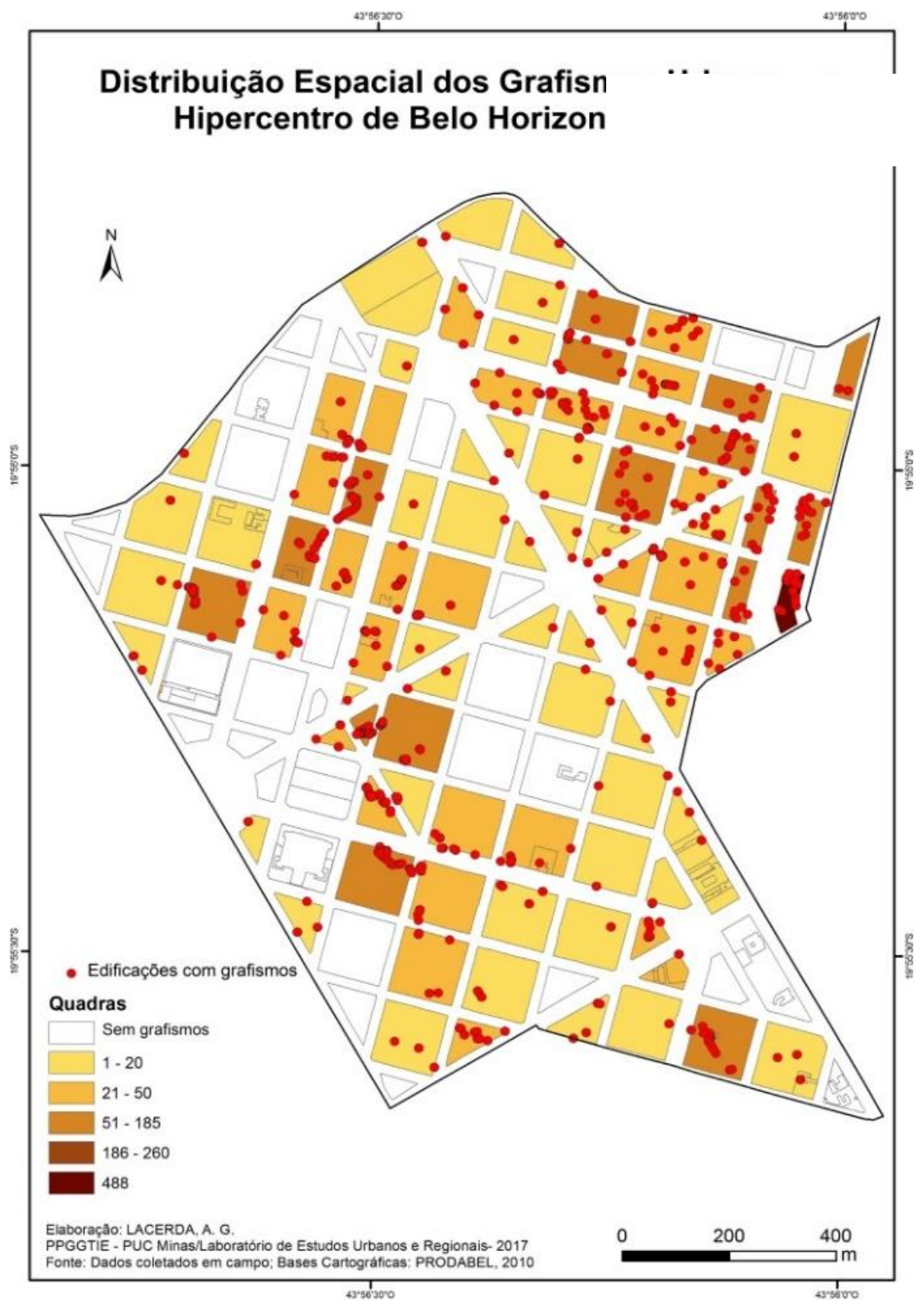

\section{CONSIDERAÇÕES FINAIS}

Os artistas de rua fazem da arte seu meio de vida, engajando em atividade militante, que desmascara convenções e provoca a reflexão sobre o significado da cidade e suas formas de uso. Esses indivíduos reconhecem que o espaço publicamente visível é regulado por regimes de propriedade e lógicas comerciais que visam, dentre outras coisas, controlar a imagem da cidade, sendo esta passível de apropriação para a realização de atos antagonistas e indômitos (IRVINE 2012). Esses artistas realizam intervenções na paisagem da cidade de modo a demonstrar como o espaço urbano é parcial (ULMER, 2017), denunciando as suas contradições e buscando voz e vez.

A apropriação subversiva dos espaços públicos do hipercentro de Belo Horizonte nos remete a algumas importantes conclusões. Primeiramente, cabe pontuar que os artistas de rua se reapropriam e ressignificam os espaços públicos, reivindicando o seu direito à cidade (LEFEBVRE, 1996), desafiando padrões de uso e referências estéticas hegemônicos, demonstrando que a vida urbana pode ser construída de modo diverso daquele preceituado pelas concepções dominantes da realidade (ALONSO, 1998). 
Os grafismos urbanos constituem-se, portanto, em prática discursiva exercida por uma minoria social, plena de dispositivos simbólicos empregados para dar vazão às angústias e frustrações de grupos excluídos, reforçando identidades tanto individuais, como grupais (SILVA e SILVA, 2008).

A natureza subversiva e anti-hegemômica da ação dos artistas de rua faz com que o exercício de sua geograficidade se traduza na apropriação e na ressignificação do espaço urbano, resultando na sua territorialização. Os artistas de rua lutam contra os atores hegemônicos (poder público, agentes privados, grupos sociais conservadores, etc.) pelo direito de expressão e controle da paisagem urbana, ao mesmo tempo em que disputam entre si os suportes sobre os quais os grafismos são aplicados, desenvolvendo territorialidades nas escalas do muro, do prédio e do quarteirão.

Os resultados apresentados neste estudo revelam que a ação dos artistas de rua é geradora de uma dialética construção de territorialidades horizontais e verticais. Os mapas apresentados ilustram as territorialidades horizontais, consubstanciadas nos segmentos de rua e quarteirões dominados por certos indivíduos ou grupos de artistas. Por outro lado, os resultados da catalogação dos grafismos urbanos são indicativos da presença de territorialidades verticais, fruto das disputas estabelecidas entre os artistas de rua por posições estratégicas em muros e fachadas sobre as quais as suas marcas são deixadas. Na construção de territorialidades verticais têm destaque a parte mais alta das edificações e as porções das fachadas de mais difícil acesso, locais que conferem aos artistas maior visibilidade e prestígio entre os pares. Locais, portanto, revestidos de grande simbolismo.

Mediando a disputa pelos territórios horizontais e verticais figura um importante código de ética, que rechaça e condena a prática do "atropelo". Afinal, o fragmento do muro ou da fachada sobre o qual determinado grafismo urbano é aplicado torna-se um microterritório vertical, uma extensão simbólica, um espelhamento da existência material do artista ou do grupo de artistas responsáveis pela intervenção urbana. Portanto, não se pode negar que a construção dessas territorialidades reflete a multidimensionalidade do "vivido" territorial dos artistas de rua, que operam segundo um sistema de relações existenciais e produtivistas (RAFFESTIN, 1993:159) na apropriação do espaço urbano.

Voltando ao exercício da geograficidade entre os artistas de rua de Belo Horizonte, cabe destacar que além das territorialidades já mencionadas, lugaridades também são experienciadas (SERPA, 2017). Os resultados deste estudo revelam que o Hipercentro conta com milhares de intervenções (pichações, murais, grafites, grapixos, etc.), que trazem as marcas não apenas dos grupos de artistas locais, mas também daqueles originados em outras partes de Belo Horizonte e sua região metropolitana, representando simultaneamente um local de disputa, mas também de encontro. Um espaço conector de grupos de indivíduos que compartilham pontos de vista, experiências e a vivência da negação do direito à cidade. Um espaço impregnado de simbolismo, no entorno do qual os artistas de rua gravitam criando e recriando espaços vividos. Trata-se da faceta simbólica e identitária do território (HAESBAERT 2008).

Por fim, cabe destacar que os artistas de rua, no exercício de sua prática discursiva contestatória e identitária, se adaptam aos discursos hegemônicos sub-repticiamente, adotando uma forma de resistência pacífica, que minimiza o confronto aberto. Retomando a pergunta que orientou o presente estudo, a retratação dos grafismos urbanos presentes no Hipercentro em três momentos $(2011,2015$ e 2017) é indicativa de alterações no comportamento espacial e estético dos artistas de rua, em resposta à crescente repressão e intolerância relacionadas à pichação e a crescente aceitação do grafite como forma de arte. Assiste-se, portanto, à proliferação de bombs, grapixos e estêncis - formas mais coloridas e menos abstratas de grafismo urbano - concomitantemente às mudanças observadas nas práticas da pichação, que têm privilegiado materiais e modos de aplicação mais rápidos em locais de mais fácil acesso, que permitem mais fácil evasão.

\section{AGRADECIMENTO}

Os autores registram a sua gratidão à FAPEMIG pelo apoio no desenvolvimento desta pesquisa.

\section{REFERÊNCIAS BIBLIOGRÁFICAS}

ALONSO, A. Urban Graffiti on the City Landscape. This paper was presented at Western Geography Graduate Conference, San Diego State University - February 14, 1998. 
AMORIM FILHO, O. B. A Evolução do Pensamento Geográfico e a Fenomenologia. Sociedade \& Natureza, Uberlândia, v. 11, p. 67-87, jan./dez., 1999.

BARRETO, A. Belo Horizonte: memória histórica e descritiva - história média. 2. ed. Belo Horizonte: Fundação João Pinheiro, 1996.

BELO HORIZONTE. Lei $\mathbf{n}^{\circ} \mathbf{7 1 6 6}$, de 27 de agosto de 1996. Estabelece normas e condições para parcelamento, ocupação e uso do solo urbano no município. Disponível em: <https://cmbelo-horizonte.jusbrasil.com.br/legislacao/237741/lei-7166-96>. Acesso em: 7 set. 2018.

Lei no 6995, de 22 de novembro de 1995. Proíbe a pichação no âmbito do município. Disponível em : https://cm-belo-horizonte.jusbrasil.com.br/legislacao/237779/lei6995-95. Acesso em: 7 de set. 2018.

Plano de reabilitação do hipercentro de Belo Horizonte, 2007. Disponível em: < https://prefeitura.pbh.gov.br/sites/default/files/estrutura-de-governo/politicaurbana/2018/planejamentourbano/publicacaoes plano reabilita\%C3\%A7\%C3\%A3o hipercentro bh.pdf>. Acesso em: 12 set. 2018.

Lei $\mathbf{n}^{\circ} \mathbf{1 0 0 5 9}$, de 28 de dezembro de 2010. Dispõe sobre a política municipal antipichação. Diário Oficial do Município. Disponível em: $<$ http://portal6.pbh.gov.br/dom/iniciaEdicao.do?method=DetalheArtigo\&pk=1049831>. Acesso em: 7 set. 2018.

Lei $\mathbf{n}^{\circ} \mathbf{1 0 . 9 3 1}$, de 17 de junho de 2016. Institui política contra a prática de pichação. Diário Oficial do Município. Disponível em: $<$ http://portal6.pbh.gov.br/dom/iniciaEdicao.do?method=DetalheArtigo\&pk=1164394>. Acesso em: 7 set. 2018.

Edital de concurso público no 001/2017. Seleção de propostas de murais de arte urbana - gentileza. Disponível em file:///C:/Users/alexandre/Dropbox/PUBLICA\%C3\%87\%C3\%95ES/REF\%20BIBLIOGRAFICA\% 20PIXACAO\%20GRAFITE\%20E\%20STREET\%20ART/concurso_001_2017_murais_de_arte_u rbana_gentileza.pdf. Acesso em 7 set. de 2018.

Programa Gentileza apoia ação em favor da arte urbana em BH. Disponível em: https://prefeitura.pbh.gov.br/noticias/programa-gentileza-apoia-acao-em-favorda-arte-urbana-em-bh. Acesso em: 7 set. de 2018a.

Programa Gentileza começa a tomar forma na cidade. Disponível em: https://prefeitura.pbh.gov.br/noticias/programa-gentileza-comeca-tomar-forma-na-cidade Acesso em 7 set. de $2018 \mathrm{~b}$.

BRANDÃO, C. M.; SCHMIDT, E.. Marcas urbanas: a arte do graffiti e as relações sócioambientais dos sujeitos. Revista Prâksis, Rio Grande do Sul, v.1, p. 43-50, $1^{\circ}$ sem. 2008.

CÂMARA DE DIRETORES LOJISTAS DE BELO HORIZONTE. Boletim CDL em ação. Notícias para o Comércio. Boletim CDL em Ação. Edição 8. Janeiro/Fevereiro 2017. Disponível em: $<$ http://www.cdlbh.com.br/portal/54/Noticias/Noticias para o Comercio $>$. Acesso em: 12 set. 2018. https://doi.org/10.18605/2175-7275/cereus.v8nespp12

DARDEL, E. O Homem e a Terra: natureza da realidade geográfica.1. ed. São Paulo: Perspectiva, 2011.

DINIZ, A. M. A.; FERREIRA, R. G. B.; ALCÂNTARA, S. A. Pichação, paisagem e território no Hipercentro de Belo Horizonte. Cadernos de Arquitetura e Urbanismo, v. 22, n. 30, p. 84103, 2015. https://doi.org/10.5752/P.2316-1752.2015v22n30p84

DINIZ, A. M. A.; FERREIRA, R. G. B.; LACERDA, A. G. Territórios renitentes: os efeitos das políticas repressivas à pichação em Belo Horizonte (2011-2015). Caderno de Geografia, v. 27, n. 50, 2017.. https://doi.org/10.5752/p.2318-2962.2017v27n50p589

PRODABEL - EMPRESA DE INFORMÁTICA E INFORMAÇÃO DO MUNICÍPIO DE BELO HORIZONTE: Base cartográfica: Quadras e Arruamento. Belo Horizonte: PRODABEL, 2010. Disponível em https://monitorabh.pbh.gov.br/mapas-georreferenciados. Acesso em: 13 de fevereiro de 2018.

GOMES, P. C. da C. A condição urbana; Ensaios de Geopolítica da cidade. Rio de Janeiro: Bertrand Brasil, 2002 
HAESBAERT, R.. Dilema de conceitos: espaço-território e contenção territorial. In: SAQUET, M. A. e SPOSITO, E. S. (Orgs.). Territórios e territorialidades: teorias, processos e conflitos. São Paulo: Expressão Popular UNESP, 2008. p. 95-120.

IRVINE, M. The work on the street: Street art and visual culture. In B. Sandywell and I. Heywood (Eds.), Handbook of visual culture (pp. 235-278). London, England: Palgrave. 2012. https://doi.org/10.5040/9781474294140.ch-010

ISNARDIS, A. Pinturas rupestres urbanas: uma etnoarqueologia das pichações em Belo $\begin{array}{llll}\text { Horizonte. Revista de Arqueologia, } & \text { n. 10, p. } & 1997 .\end{array}$ https://doi.org/10.24885/sab.v10i1.124

JORNAL ESTADO DE MINAS. Kalil visita projeto em viaduto de $\mathrm{BH}$ e fala de ação contra grafiteiro que escreve em lixeiras. Estado de Minas, Belo Horizonte, 18 set. 2017 Disponível em: https://www.em.com.br/app/noticia/gerais/2017/09/18/interna_gerais,901302/kalil-visitagrafiteiros-do-projeto-profeta-gentileza-em-viaduto-de-bh.shtml. Acesso em: 7 set. de 2018.

LEFEBVRE, H. (1996). Writings on cities (E. Kofman \& E. Lebas, Trans.). Oxford, UK: Blackwell.

LEWISOHN, C. Street Art: the Graffiti Revolution. London: Tate Publishing. 2010. 160 p.

MEDEIROS, R. M. V.. Território, Espaço de Identidade. In: SAQUET, M. A. e SPOSITO, E. S. (Orgs.). Territórios e territorialidades: teorias, processos e conflitos. São Paulo: Expressão Popular UNESP, 2008. p. 217-228.

MILES, M. Art. Space and the City: Public Art and Urban Futures. London: Routledge, 1997 RAFFESTIN, C. Por uma geografia do poder. 1. ed. São Paulo: Ática S.A, 1993. 269p.

A produção das estruturas territoriais e sua representação. In: SAQUET, M. A. e SPOSITO, E. S. (Orgs.). Territórios e territorialidades: teorias, processos e conflitos. São Paulo: Expressão Popular UNESP, 2008, p. 17-36.

RAMOS, C. M. A.. Grafite, pichação \& Cia. 1. ed. São Paulo: Editora Annablume, 1994

SANTOS, M. A natureza do espaço. Técnica e Tempo, Razão e Emoção. 4. ed. São Paulo: EDUSP, 2002.

SAQUET, M. A.. Por uma abordagem territorial. In: SAQUET, M. A. e SPOSITO, E. S. (Orgs.). Territórios e territorialidades: teorias, processos e conflitos. São Paulo: Expressão Popular UNESP, 2008. p. 73-94.

SERPA, A. Ser lugar e ser território como experiências do ser-no-mundo: um exercício de existencialismo geográfico. Geousp - Espaço e Tempo, São Paulo, v. 21, n. 2, p. 586-600, $2^{\circ}$ sem. 2017. https://doi.org/10.11606/issn.2179-0892.geousp.2017.125427

SILVA, A. L. S. V.. Grafite: Manifestação de Arte Urbana. On the w@terfront, Vol. 11, Oct. 2008. Pp 131-141

SILVA e SILVA, W.. A trajetória do graffiti mundial. Revista Ohun, Salvador, n. 4, p.212-231, dez. 2008.

SOARES, F. B. F.Nóis pixa, você pinta, vamos ver quem tem mais tinta: direito à cidade e resistência nos espaços urbanos. Dissertação (mestrado em Direito) - Faculdade de Direito, Universidade Federal de Minas Gerais, p. 150. 2016.

SOUZA, M. L. O território: sobre espaço e poder, autonomia e desenvolvimento. In: CASTRO, I. E.; GOMES, P. C. C.; CORRÊA, R. L. (Orgs.). Geografia: conceitos e temas. 2. ed. Rio de Janeiro: Bertrand Brasil, 1995. Cap. 3, p. 77-116.

SOUZA, M. L. Os conceitos fundamentais da pesquisa sócio-espacial. Rio de Janeiro: Bertrand Brasil, 2013.

ULMER, J. B. Writing Urban Space: Street Art, Democracy, and Photographic Cartography. Cultural Studies Critical Methodologies 17(6) 2017, pp. 491- 502. https://doi.org/10.1177/1532708616655818

Recebido em: 28/09/2018

Aceito para publicação em: 02/04/2019

$\begin{array}{llllll}\text { Caminhos de Geografia } & \text { Uberlândia-MG } & \text { v. 20, n. } 71 & \text { Setembro/2019 } & \text { p.85-103 } & \text { Página } 103\end{array}$

